\title{
MEASURING POVERTY CYCLES IN THE U.S. 1959-2013
}

\author{
Marinko ŠKARE ${ }^{*}$, Romina PRŽIKLAS DRUŽETA ${ }^{1}$, Damian ŠKARE ${ }^{2}$ \\ ${ }^{1}$ Faculty of Economics and Tourism "Dr. Mijo Mirković", Juraj Dobrila University of Pula, \\ Preradovićeva 1/1, 52100 Pula, Croatia \\ ${ }^{2}$ School of Economics Pula, Kovačićeva ul. 3, 52100 Pula, Croatia
}

Received 1 August 2017; accepted 26 November 2017

\begin{abstract}
This paper aims to shed light on the nature of poverty as a dynamic process by examining poverty cycles, their magnitudes, and their asymmetry. The designated benchmark country is the USA due to the availability of time series data making comprehensive analyses possible. We use Harding and Pagan (2002) and the Cardinale and Taylor (2009) model to isolate poverty cycles in the U.S. during 1959-2013. Once isolated, we test the poverty cycles for duration dependency, and their synchronization with the U.S. business cycles observed over the same period. We find that poverty dynamics measured through poverty cycles differ for alternative poverty rate indicators. Another critical point is the magnitude of change in the poverty cycles. Prolonged and more volatile poverty cycles have a significant adverse impact on people and families facing them. That is particularly important for policymakers who should rethink poverty policy guidelines aimed at helping people with more volatile poverty cycles first. Our is the first study, to our knowledge, to isolate poverty cycles and focus on their nature. Poverty cycles should attract more attention from policymakers since they more accurately assess nations' economic well-being than output (GDP).
\end{abstract}

Keywords: poverty cycles, poverty, duration dependence, turning points, amplitudes in poverty cycles, U.S.

JEL Classification: C22, E3, I32, P36.

\section{Introduction}

The large body of literature is devoted to the study of business cycles, but none is focusing on the study of another significant economic phenomenon - poverty cycles. We believe business cycles and poverty cycles are two faces of the same coin - economic growth. Poverty cycles show a clear pattern, time dependence, and asymmetry, making them identical to business cycles. Identifying and measuring poverty cycles is essential to understand the true nature of poverty and factors behind it. Output cycles are proxies for aggregate well-being in the body of literature. Poverty cycles serve as better proxies for aggregate well-being, but they have not been investigated in general economic literature yet.

*Corresponding author. E-mail: mskare@unipu.hr

This is an Open Access article distributed under the terms of the Creative Commons Attribution License (http://creativecommons. org/licenses/by/4.0/), which permits unrestricted use, distribution, and reproduction in any medium, provided the original author and source are credited. 
This study is the first to address the importance of measuring poverty cycles. Monitoring poverty cycle is the key to understanding the true nature of poverty as a socio-economic phenomenon. Duration dependence, asymmetry, and persistence in poverty cycles are significant so that we can learn the nature of poverty dynamics. Knowing the true nature of poverty dynamics is essential for policymakers so they can design effective policy set to fight against poverty. To do so, they must know how quickly people fall into poverty and how long it takes for them to escape. Can we trace a pattern in the dynamics behind poverty? Is there a pattern in the first place, if there is one, can we measure and isolate it for further study? How are poverty cycles (if we can trace them) synchronized with business cycles and is there a causal link between them? All these issues are a central element in designing an efficient anti-poverty policy framework. Since they remain unanswered, the purpose of this study is to examine them and establish a possible causal and empirical relationship driving poverty cycles.

Most literature examining poverty focus on its dynamics (Bane \& Ellwood, 1986), transitioning in and out of the poverty (Ruggles \& Williams, 1986), poverty among children (Bradbury, Jenkins, \& Micklewright, 2001). Carter and Barrett (2006) study the structural aspect of poverty while Biewen (2006) looks into the chronic nature of poverty in Germany. Muyanga, Jayne, and Burke (2013) study the characteristics of small farm households' poverty transition in Kenya while Yelognisse (2016) explores poverty determinants and persistence in Benin. The importance of understanding the true nature of poverty has been emphasized by several researchers in their studies Perry, Arias, López, Maloney, and Servén (2006), Bane and Ellwood (1986), Oxley, Dang, and Antolín (2000), Mangum, G. L., Mangum, S. L., and Sum (2003). Not a single study has attempted to measure and isolate poverty cycles, however, at least to our present knowledge.

We use the methodology developed by Harding and Pagan (2002) and Cardinale and Taylor (2009) to isolate poverty cycles in the U.S. during 1959-2013. Our study has two research objectives: one is to isolate and measure poverty cycles and the second is to study duration dependence (Mudambi a\& Taylor, 1995), asymmetry, the persistence of the poverty cycles and their synchronization with business cycles. Since poverty cycles are not under study in the literature, general economic literature assumes poverty dynamics/transition affected by output cycles. Although theoretical arguments in favor of this thesis (output being the most significant aggregated well-being indicator) appear to be strong, poverty is still a multidimensional phenomenon demanding an explanation. Learning a nature of the poverty cycles should bring new light to the pro-poor and pro-growth policy discussion (Kakwani, Neri, \& Son, 2010).

The finding of this research is expected to actively encourage future research on the issue of poverty cycles since (based on this study's results) it is our firm conviction that it is not possible to understand poverty without identifying poverty cycle shapes. Understanding poverty cycles shapes, poverty persistence, and duration for different poverty groups (as measured by the U.S. Census Bureau), as well as their synchronization with business cycles, can be of direct assistance to policymakers in designing efficient poverty policy sets.

The rest of the article is structured as follows: theoretical plausibility and the need for studying poverty cycles in the body of literature is explained and structurally presented in 
the next section. Section three displays the data used for the analysis and the methodological framework applied to isolate poverty cycles in the U.S. 1959-2013. In the fourth section, measured and isolated U.S. poverty cycles are analyzed and explained (cycle shapes) and the level of synchronization between poverty cycles and output cycles. Section five present concluding remarks and discussion of the arguments in favor of future studies on poverty cycles, in conjunction with acknowledging the importance of the matter for the field of general economics together with the present limitation of this study consisting of data limitations and methodological constraints.

\section{Poverty cycles theoretical plausibility}

In economic thought, the subject became a burning theme in the $20^{\text {th }}$ century. Interest in the subject became intense after the 1970s, but the early efforts to comprehend the nature of poverty lack the availability of longitudinal data.

Fact is that mainstream poverty analyses have failed to address the dynamics of poverty and to answer the following questions; Is poverty a temporary condition? What types of individuals or households are more likely to grow in the "permanent" or "transitory" poverty? Is the cycle of poverty volatile?

These issues have significant implications for policy direction and can be of top priority for policymakers, especially today, where many economies meet up with the lack of financial resources.

There is a growing interest in examining the transition of poverty (Bane \& Ellwood, 1986; Ruggles \& Williams, 1986; Oxley et al., 2000; Hulme \& Shepard, 2003; Addison, Hulme, \& Kanbur, 2009; Mosse, 2010; Muyanga et al., 2013; Yelognisse, 2016; and others) but there has not been an attempt to observe the cycles of poverty and business together.

The traditional development theory looks at business cycles, and poverty cycles separately, opposing poverty traps theory (Adato, Carter, \& May, 2006).

Table 1 displays a historical review of research on poverty dynamics.

According to Perry et al. (2006), the theoretical approach of poverty-trap models (traditional neoclassical growth model) which explain some facts on the growth-poverty model link is inappropriate. That is because of the disappointing growth performance of developing countries relative to the developed and because these strategies do not take the fact that growth will be problematic unless the constraints affecting the poor are also taken into account. This direction of causality from poverty to growth, in turn, opens the door to the existence of poverty traps, where poverty and growth interact in a vicious circle where high poverty leads to low growth and low growth in turns leads to high poverty.

According to Bane and Ellwood (1986), questions about the allocation of resources can be better be answered when the characteristics of the poor are understood. Oil price shock also has a substantial impact on business conditions affecting economic growth (Sodeyfi \& Katircioglu, 2016).

According to Oxley et al. (2000), poverty rates are a helpful indicator of the level of poverty in a country during a specific period, but they do not provide valuable information about the extent of the mobility of going in and out of poverty (Krishna, 2006) or about the 
length of time people remain in poverty. Such information is essential for policymakers due to different policies and their responses. Promotion of social inclusion policies is also central in bringing poverty down mainly in countries with high unemployment rates (Simionescu, 2016).

Table 1. Description and findings in some studies of poverty dynamics (source: author's review)

\begin{tabular}{|c|c|c|}
\hline Author & Description & Results \\
\hline $\begin{array}{l}\text { Bane and Ellwood } \\
\text { (1986) }\end{array}$ & $\begin{array}{l}\text { The authors examine the dynamics } \\
\text { of poverty. }\end{array}$ & $\begin{array}{l}\text { The results indicate that the majority } \\
\text { of poor persons at any time are in the } \\
\text { midst of a rather long spell of poverty. } \\
\text { They found out that less than } 40 \text { percent } \\
\text { of poverty spells begin because of a } \\
\text { drop in the heads earnings, while } 60 \\
\text { percent of the spells end when the } \\
\text { heads earnings increase. }\end{array}$ \\
\hline $\begin{array}{l}\text { Ruggles and } \\
\text { Williams (1986) }\end{array}$ & $\begin{array}{l}\text { The paper uses data from the SIPP } \\
\text { (Survey of Income and program } \\
\text { participation) to examine transitions } \\
\text { into and out of poverty. The focus } \\
\text { of the paper is on six specific } \\
\text { demographic and employment- } \\
\text { related events and their association } \\
\text { with becoming poor or leaving } \\
\text { poverty. Examination of the } \\
\text { relationship between these events } \\
\text { and poverty transitions for the } \\
\text { population as a whole is followed by } \\
\text { similar analysis for people in four } \\
\text { specific types of families; female- } \\
\text { headed families, families headed } \\
\text { by males or by married couples, } \\
\text { families with elderly members and } \\
\text { families with no elderly members. }\end{array}$ & $\begin{array}{l}\text { The paper has found significant } \\
\text { correlations between the life events } \\
\text { examined and transitions into and out } \\
\text { of poverty. }\end{array}$ \\
\hline Oxley et al. (2000) & $\begin{array}{l}\text { The paper explores poverty } \\
\text { dynamics in six OECD countries. } \\
\text { The Panel data provide complete } \\
\text { information about poverty and } \\
\text { permits a better analysis of factors } \\
\text { associated with the entry and exit } \\
\text { from poverty and the length of stay. }\end{array}$ & $\begin{array}{l}\text { One of the main conclusion is that } \\
\text { the probability of exiting poverty } \\
\text { falls behind previous experiences in } \\
\text { poverty, at the same time there is a high } \\
\text { probability of falling back into poverty. } \\
\text { Obtaining or losing employment is } \\
\text { particularly significant for transitions } \\
\text { into and out of poverty. }\end{array}$ \\
\hline $\begin{array}{l}\text { Bradbury et al. } \\
\text { (2001) }\end{array}$ & $\begin{array}{l}\text { The book is about } \\
\text { poverty among children and } \\
\text { about the dynamic aspects of that } \\
\text { poverty - how individual children } \\
\text { move into and out of being poor. }\end{array}$ & $\begin{array}{l}\text { The paper found that good policy } \\
\text { analysis requires several ingredients: } \\
\text { detailed information about the nature } \\
\text { of a problem and its consequences and } \\
\text { what the causes are, plus knowledge } \\
\text { of the efficacy of alternative policy } \\
\text { programs. }\end{array}$ \\
\hline
\end{tabular}


End of Table 1

\begin{tabular}{|c|c|c|}
\hline Author & Description & Results \\
\hline $\begin{array}{l}\text { Carter and Barrett } \\
(2006)\end{array}$ & $\begin{array}{l}\text { The paper develops an asset-based } \\
\text { approach to poverty analysis that } \\
\text { makes it possible to distinguish } \\
\text { deep-rooted, persistent structural } \\
\text { poverty from poverty that passes } \\
\text { naturally with time due to } \\
\text { systematic growth processes. }\end{array}$ & $\begin{array}{l}\text { Identification of the asset poverty } \\
\text { line makes it possible to distinguish } \\
\text { structural poverty transition from } \\
\text { stochastic poverty transitions. } \\
\text { Identification of the dynamic asset } \\
\text { poverty threshold permits a further } \\
\text { refinement of poverty measurement, } \\
\text { making it possible to distinguish } \\
\text { households likely to escape poverty over } \\
\text { the longer term from those apparently } \\
\text { mired in a poverty trap. }\end{array}$ \\
\hline Biewen (2006) & $\begin{array}{l}\text { Based on a multiple spells approach, } \\
\text { this paper studies the extent and the } \\
\text { composition of chronic poverty in } \\
\text { Germany. }\end{array}$ & $\begin{array}{l}\text { The results indicate that about one-third } \\
\text { of cross-sectional poverty in a given } \\
\text { year is chronic. The characteristics } \\
\text { that are most closely associated with } \\
\text { long-term poverty are economic } \\
\text { inactivity and pensioner status. The } \\
\text { number of children and the gender of } \\
\text { the household head seems to have no } \\
\text { systematic effect. }\end{array}$ \\
\hline Stevens (2012) & $\begin{array}{l}\text { The chapter discusses transitions } \\
\text { into and out of poverty. }\end{array}$ & $\begin{array}{l}\text { Understanding the causes and timing } \\
\text { of transitions into and out of poverty is } \\
\text { crucial in refining distinctions between } \\
\text { short-term poverty, which may reflect } \\
\text { transitional life-cycle stages or short- } \\
\text { term employment shocks, and long- } \\
\text { term poverty which may be associated } \\
\text { with more permanent limitations on } \\
\text { earnings potential, human capital, and } \\
\text { family structure. Poverty transitions also } \\
\text { provide an appealing framework for } \\
\text { measuring the persistence of poverty. }\end{array}$ \\
\hline $\begin{array}{l}\text { Muyanga et al. } \\
\text { (2013) }\end{array}$ & $\begin{array}{l}\text { This study identifies the factors } \\
\text { associated with smallholder farm } \\
\text { households that have risen out of } \\
\text { poverty or descended into poverty } \\
\text { between } 1997 \text { and } 2007 \text { in Kenya. }\end{array}$ & $\begin{array}{l}\text { The results indicate that household } \\
\text { welfare dynamics are associated with } \\
\text { a disparate set of idiosyncratic and } \\
\text { unexpected shocks, such as death and } \\
\text { chronic illness, demographic factors, } \\
\text { proximity to infrastructural facilities, } \\
\text { as well as intergenerational wealth } \\
\text { transfers. }\end{array}$ \\
\hline Yelognisse (2016) & $\begin{array}{l}\text { The purpose of the paper is } \\
\text { to examine the determinants } \\
\text { of poverty and the persistence } \\
\text { of poverty in Benin using a } \\
\text { longitudinal data for the years } \\
2006-2011 \text {. }\end{array}$ & $\begin{array}{l}\text { This paper finds that households } \\
\text { demographic and socio-economic } \\
\text { characteristics are strongly correlated } \\
\text { with their poverty status. It also finds } \\
\text { a robust evidence of persistence of } \\
\text { poverty (being poor in a year increases } \\
\text { the likelihood of remaining poor in the } \\
\text { following years. }\end{array}$ \\
\hline
\end{tabular}


Mangum et al. (2003) tried to research why poverty so persistently plaques a substantial number of individuals and households in the wealthiest nation in the world. What is it that determines how many are poor in any society? Given that, what explains who are to be those poor? Microfinance framework for fighting poverty is also not working well as is the case in Pakistan (Khan, Shaorong, \& Ullah, 2017). Foreign remittance appears to be more efficient tools in fighting poverty with a positive impact on poverty alleviation (Azam, Haseeb, \& Samsudin, 2016).

The empirical literature on the poverty - growth relationship is substantial but the question of how important growth in average income is for poverty reduction remains. To provide a clear answer to this question, we must investigate the true dynamic nature of poverty cycles.

\section{U.S. poverty cycles extraction, data, and measurement}

Following Ohn, Taylor, and Pagan (2004) and Cardinale and Taylor (2009), we isolate poverty cycles in the U.S. over 1959-2013 for individuals and households. We use data not later of 2013 because of the constraints in the availability of poverty data for all poverty categories we monitor in this study to be able to compare between them. The results are presented in Figures 1-2 and Tables 1-2. To isolate poverty cycles in the U.S., we use stata program sbbq (Harding \& Pagan, 2002) and sbbot (Cardinale \& Taylor, 2009).

From Figures 1(a)-1(d) we can see there is a significant degree of synchronization between business cycles and poverty cycles in the U.S. This was expected in a way but large asymmetries occur when taking into account the different poverty indicators that can be observed. Poverty cycles are not perfectly synchronized with business cycles. For example, poverty cycles completely 'missed' the recession of April 1960 to February 1961 (short, monetary recession due to Federal Reserve rising interest rates). Other turning points both for business and poverty cycles appear to be highly synchronized. Another important feature of poverty cycles is that sometimes they precede (lead) and on other occasions delay (lag) business cycles. Conditional on rising output, poverty rate exhibits sharp or less downward trend differing for alternative poverty indicators (family or individual poverty characteristics). Poverty cycles for (all people) and (families) show similar behavior and high synchronization with business cycles. Poverty cycles for (families, unrelated individuals) on the other hand do not show the same level of synchronization. From 8 episodes of contraction (since 1959), only 5 of them are synchronized with poverty cycles. Business cycles seem to affect poverty rates of unrelated individuals less about the effects on all people, families or families with the female householder. Downswings or upswings in output cycles exhibit low impact on poverty dynamics of unrelated individuals. Poverty cycles isolated for families with female householders show a completely different picture. They are highly synchronized with business cycles and usually precede them and last longer. Families with female householders are thus highly impacted by the downswings or upswings in output cycles (gender gap impact less government support for gender equality policies). The degree of synchronization between poverty cycles (depending on the poverty thresholds that vary by size of family and the age of the members) reveals the "flow" in trickle-down economics. Social protection buffer, lower poverty threshold (marginal costs about the poverty line) and more steady income to the poverty ratio during downswings (income persistence to the crisis). During the time of crisis, 
a)

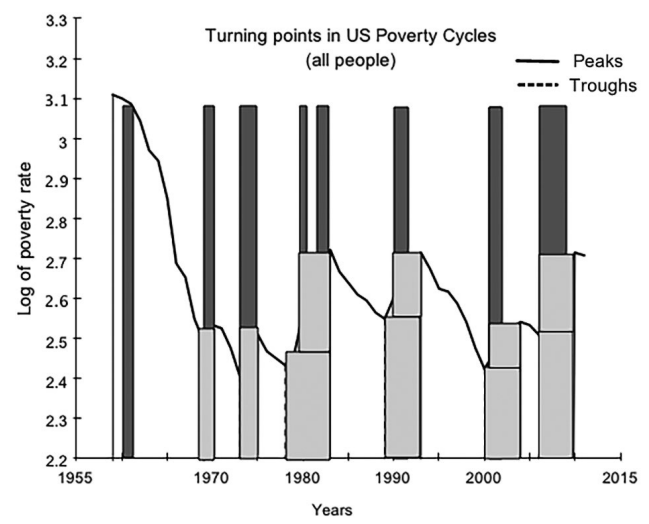

c)

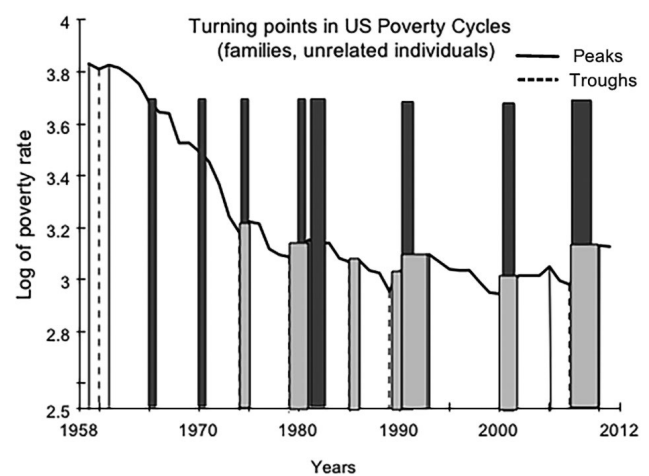

b)

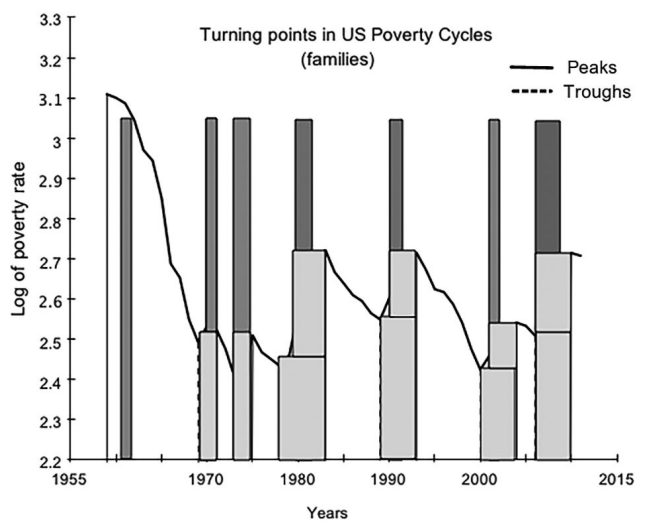

d)

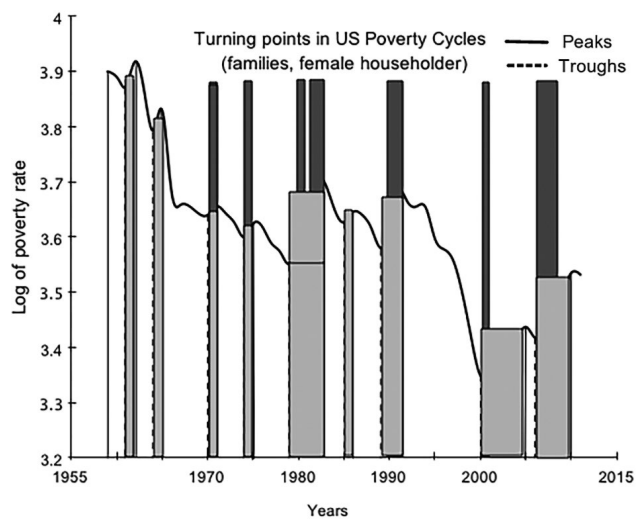

Figure 1. U.S. Poverty and business cycles: a - all people; b - families; $\mathrm{c}$ - unrelated individuals; $\mathrm{d}$ - families, female householder (source: authors' calculations based on data from US Census Bureau)

Notes: Turning points in the poverty cycles were calculated using SBBQ: Stata module to implement the Harding and Pagan (2002) business cycle dating algorithm, author Philippe Bracke and BBQ program, author Adrian Pagan.

median and mean income in the U.S. for unrelated individuals decline faster about the household income (two member families). That is, the median income for unrelated individuals is falling more sharply than the median income for all people, families, and families with female householders. However, poverty cycles are less synchronized with business cycles for unrelated individuals than for all people, families, and families with female householders (Alem, 2015). Unrelated individuals receive less median income during downswings but remain less vulnerable to poverty cycles. One possible explanation is that during downswings median and mean income for unrelated individuals are falling harder about the median and mean income for all people, families, and families with female householders. Nevertheless, during downswings, weighted average poverty thresholds for families of the specified size are rising faster about that of unrelated individuals. Unrelated individuals during recession receive less 
median and mean income, but at the same time, they are less vulnerable to poverty cycles since their weighted average poverty threshold is not rising as fast as those for all people, families, and families with female householders.

\section{Poverty cycles in the US: what drives poverty?}

Figure 2 shows poverty cycles for the U.S. period of 1959-2013 using the procedure established by Harding and Pagan (2002). The algorithm used (turning point location) identified six (6) peaks and six (6) troughs over the observed period (all people living in poverty series). Poverty cycle reference dates and duration are presented in Table 1 . Since we use various poverty rates as defined by the U.S. Census Bureau (poverty status of people by family relationship), four individual poverty cycles graphs are displayed in Figure 2. Figure (2a) shows turning points and reference poverty cycles for all people living in poverty, (2b) for families classified as poor, (2c) for poor families with female householders, no husband present and (2d) for unrelated individuals below the poverty threshold.

As shown in Figures 2(a)-2(d), Harding and Pagan (2002) the algorithm for identifying turning points in US poverty rates fits the observed data accurately. Poverty dynamics measured through identified poverty cycles differ for alternative poverty rate indicators. Poverty cycles measured for all people and families living in poverty show similar behavior. Poverty cycles for families with female householders and families with unrelated individuals display different dynamics. Another critical point is the magnitude of change in poverty cycles. The magnitude of change differs for all poverty cycles identified in this study. For example, poverty cycles for all poor people and poor families move together in time, but the magnitude of change is different. Poverty volatility is mostly high in the families with female householders and families with unrelated individuals. Poverty cycle dynamics for different poverty indicators under observation bring up an important conclusion - poverty dynamics differ significantly among people and different types of families. This fact is particularly important for policymakers, who should rethink poverty policy guidelines. Since poverty differently affects people and families (depending on the structure, age, education, household gender), measures to combat poverty must consider this fact. That means that policy actions against poverty should be targeted toward the more vulnerable population first, i.e., those with more volatile poverty cycles. A highly volatile poverty cycle means recurrent poverty cycle episodes, having more profound repercussion on individuals and family well-being. Targeting poverty policy actions toward people and families with less volatile poverty cycles (lover poverty hazard) could prevent them from falling into poverty. On the other hand, this would mean that people and families with higher poverty hazard (higher volatility in poverty cycles) would face poverty cycles more frequently. Prolonged and more volatile poverty cycles have a substantial adverse impact on people and families facing them. Poverty persistence probability for these groups increases proportionally with the level of poverty hazard (volatility). Thus, higher volatility in poverty cycles leads to poverty persistence. Therefore, policymakers' actions confronting poverty must be conveyed to individuals and families with higher poverty hazard (strongly volatile poverty cycles) first. Constant poverty cycles monitoring for different poverty groups would dramatically improve the efficiency of poverty-fighting actions and policies. 
a)

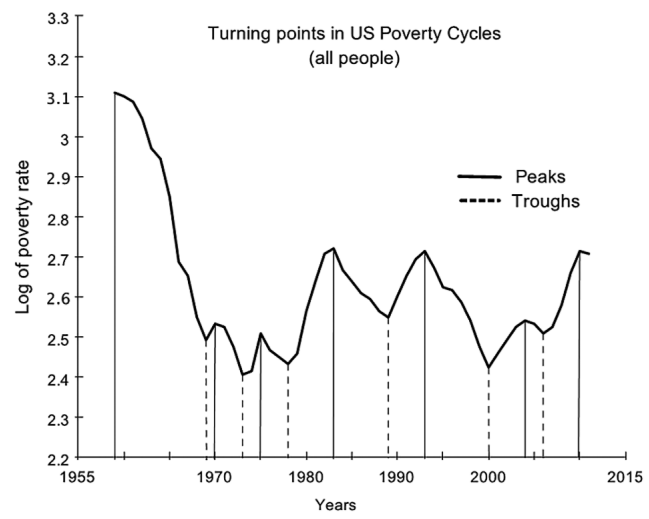

c)

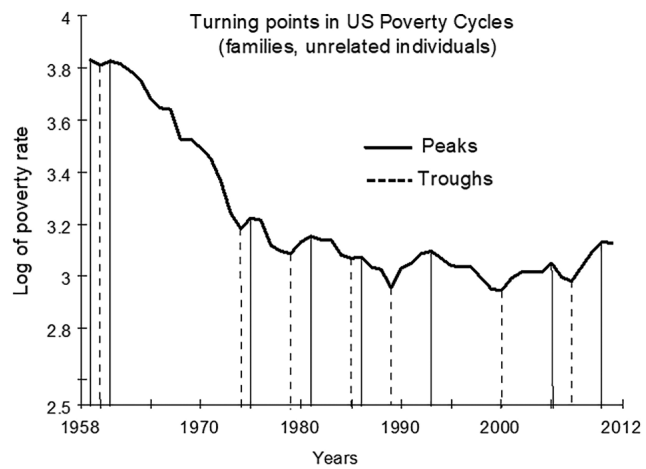

b)

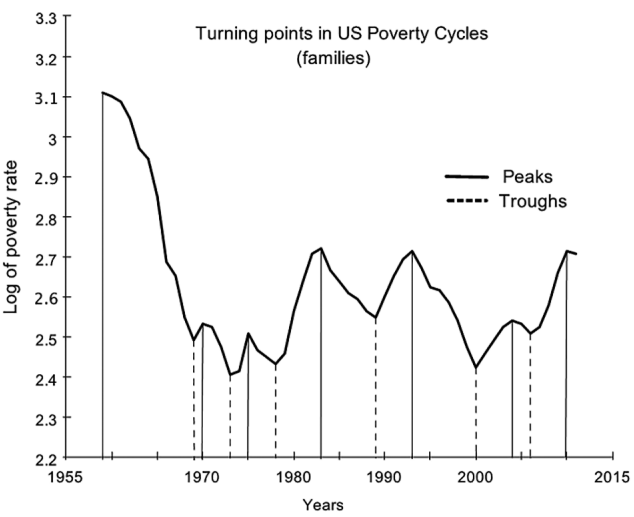

d)

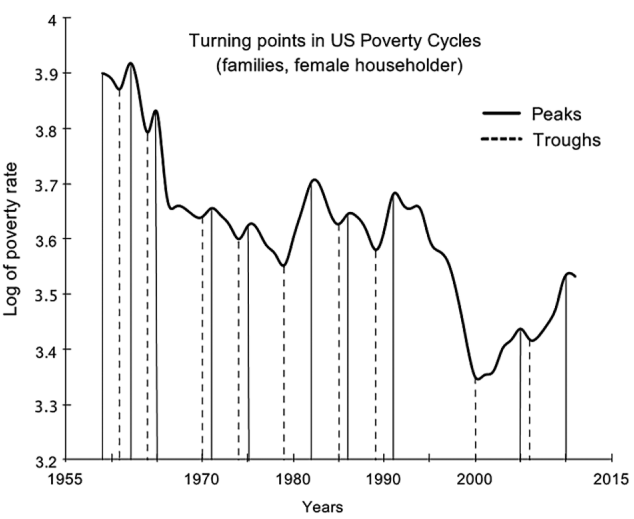

Figure 2. US Poverty cycle with turning points: a - all people; b - families; $\mathrm{c}$ - unrelated individuals; $\mathrm{d}$ - families, female householder (source: authors' calculations based on data from US Census Bureau) Notes: Turning points in the poverty cycles were calculated using SBBQ: Stata module to implement the Harding and Pagan (2002) business cycle dating algorithm, author Philippe Bracke and BBQ program, author Adrian Pagan.

\section{A. Poverty cycles in US 1959-2013}

Tables 1 and 2 show poverty cycle dates (turning points) and duration over 1959-2013 for four official (U.S. Census Bureau) poverty indicators defined before.

\section{Poverty cycle shapes and duration analysis. - (all people)}

Downswings (contraction) in poverty rate are identified as affluence while upswings (expansion) are termed deprivation (see Figure 3).

The peak in poverty rate resulting from deprivation will be referred to as (persistence) and trough appearing as the result of affluence is termed (opulence). For poverty cycles (all people) there are 6 completed spells of affluence and 6 completed spells of deprivation. The average length of the affluence phase is 4.57 , and for the deprivation phase, it is 3.33 years. 
Table 1. US poverty cycles dates (all people and families): 1959-2013 (source: author's calculations)

\begin{tabular}{|c|c|c|c|c|c|}
\hline \multicolumn{2}{|c|}{ REFERENCE DATES } & \multicolumn{4}{|c|}{ DURATIONS IN YEARS } \\
\hline \multirow[b]{2}{*}{ Peak } & \multirow[b]{2}{*}{ Trough } & \multirow{2}{*}{$\begin{array}{c}\text { Contraction } \\
\text { Peak to } \\
\text { Trough }\end{array}$} & \multirow{2}{*}{$\begin{array}{c}\text { Expansion } \\
\begin{array}{l}\text { Previous Trough } \\
\text { to this Peak }\end{array}\end{array}$} & \multicolumn{2}{|c|}{ Cycle } \\
\hline & & & & $\begin{array}{c}\text { Trough from } \\
\text { Previous } \\
\text { Trough }\end{array}$ & $\begin{array}{c}\text { Peak from } \\
\text { Previous Peak }\end{array}$ \\
\hline \multicolumn{6}{|c|}{ POVERTY CYCLES (ALL PEOPLE) } \\
\hline 1959 & 1969 & 11 & - & - & - \\
\hline 1970 & 1973 & 3 & 1 & 4 & 11 \\
\hline 1975 & 1978 & 3 & 2 & 5 & 5 \\
\hline 1983 & 1989 & 6 & 5 & 11 & 8 \\
\hline 1993 & 2000 & 7 & 4 & 11 & 10 \\
\hline 2004 & 2006 & 2 & 4 & 6 & 11 \\
\hline 2010 & - & - & 4 & - & 6 \\
\hline \multicolumn{6}{|c|}{ SUMMARY STATISTICS } \\
\hline \multicolumn{2}{|c|}{ NUMBER OF PHASES } & 6 & 6 & & \\
\hline \multicolumn{2}{|c|}{ AVERAGE LENGHT } & 4.57 & 3.33 & & \\
\hline \multicolumn{2}{|c|}{ STANDARD DEVIATION } & 3.386 & 1.505 & & \\
\hline \multicolumn{2}{|c|}{ AVERAGE AMPLITUDE } & -0.1884 & 0.153 & & \\
\hline \multicolumn{2}{|c|}{$\begin{array}{l}\text { AVERAGE CUMULATIVE } \\
\text { MOVEMENT }\end{array}$} & -0.6974 & 0.3846 & & \\
\hline \multicolumn{6}{|c|}{ POVERTY CYCLES (FAMILIES) } \\
\hline 1959 & 1969 & 11 & - & - & - \\
\hline 1970 & 1973 & 3 & 1 & 4 & 11 \\
\hline 1975 & 1978 & 3 & 2 & 5 & 5 \\
\hline 1983 & 1989 & 6 & 5 & 11 & 8 \\
\hline 1993 & 2000 & 7 & 4 & 11 & 10 \\
\hline 2004 & 2006 & 2 & 4 & 6 & 11 \\
\hline 2010 & - & - & 4 & - & 6 \\
\hline \multicolumn{6}{|c|}{ SUMMARY STATISTICS } \\
\hline \multicolumn{2}{|c|}{ NUMBER OF PHASES } & 6 & 6 & & \\
\hline \multicolumn{2}{|c|}{ AVERAGE LENGHT } & 4.57 & 3.33 & & \\
\hline \multicolumn{2}{|c|}{ STANDARD DEVIATION } & 3.386 & 1.505 & & \\
\hline \multicolumn{2}{|c|}{ AVERAGE AMPLITUDE } & -0.2112 & 0.1694 & & \\
\hline \multicolumn{2}{|c|}{$\begin{array}{l}\text { AVERAGE CUMULATIVE } \\
\text { MOVEMENT }\end{array}$} & -0.7828 & 0.4192 & & \\
\hline
\end{tabular}

Notes: Turning points in the poverty cycles were calculated using SBBQ: Stata module to implement the Harding and Pagan (2002) business cycle dating algorithm, author Philippe Bracke and BBQ program, author Adrian Pagan. 
Table 2. US poverty cycles dates (families with female householder and unrelated individuals): 1959-2013 (source: author's calculations)

\begin{tabular}{|c|c|c|c|c|c|}
\hline \multicolumn{2}{|c|}{ REFERENCE DATES } & \multicolumn{4}{|c|}{ DURATIONS IN YEARS } \\
\hline \multirow[b]{2}{*}{ Peak } & \multirow[b]{2}{*}{ Trough } & \multirow{2}{*}{$\begin{array}{c}\text { Contraction } \\
\text { Peak to } \\
\text { Trough }\end{array}$} & \multirow{2}{*}{$\begin{array}{c}\text { Expansion } \\
\text { Previous Trough } \\
\text { to this } \\
\text { Peak }\end{array}$} & \multicolumn{2}{|c|}{ Cycle } \\
\hline & & & & $\begin{array}{c}\text { Trough from } \\
\text { Previous } \\
\text { Trough }\end{array}$ & $\begin{array}{c}\text { Peak from } \\
\text { Previous Peak }\end{array}$ \\
\hline \multicolumn{6}{|c|}{ POVERTY CYCLES (FAMILIES, UNRELATED INDIVIDUALS) } \\
\hline 1959 & 1960 & 2 & - & - & - \\
\hline 1961 & 1974 & 13 & 1 & 14 & 12 \\
\hline 1975 & 1979 & 4 & 1 & 5 & 14 \\
\hline 1981 & 1985 & 4 & 2 & 6 & 6 \\
\hline 1986 & 1989 & 3 & 1 & 4 & 5 \\
\hline 1993 & 2000 & 7 & 4 & 11 & 7 \\
\hline 2005 & 2007 & 2 & 5 & 7 & 12 \\
\hline 2010 & - & - & 3 & - & 5 \\
\hline \multicolumn{6}{|c|}{ SUMMARY STATISTICS } \\
\hline NUMBER & HASES & 7 & 7 & & \\
\hline AVERAGE & GHT & 4.375 & 2.4284 & & \\
\hline STANDAR & VIATION & 3.915 & 1.618 & & \\
\hline AVERAGE & LITUDE & -0.154 & 0.0747 & & \\
\hline $\begin{array}{l}\text { AVERAGE } \\
\text { MOVEME }\end{array}$ & IULATIVE & -0.6423 & 0.1847 & & \\
\hline \multicolumn{6}{|c|}{ POVERTY CYCLES (FAMILIES, FEMALE HOUSEHOLDER) } \\
\hline 1959 & 1961 & 3 & - & - & - \\
\hline 1962 & 1964 & 2 & 1 & 3 & 3 \\
\hline 1965 & 1970 & 5 & 1 & 6 & 3 \\
\hline 1971 & 1974 & 3 & 1 & 4 & 6 \\
\hline 1975 & 1979 & 4 & 1 & 5 & 4 \\
\hline 1982 & 1985 & 3 & 3 & 6 & 7 \\
\hline 1986 & 1989 & 3 & 1 & 4 & 4 \\
\hline 1991 & 2000 & 9 & 2 & 11 & 5 \\
\hline 2005 & 2006 & 1 & 5 & 6 & 14 \\
\hline 2010 & - & - & 4 & - & 5 \\
\hline \multicolumn{2}{|c|}{ NUMBER OF PHASES } & 9 & 9 & & \\
\hline \multicolumn{2}{|c|}{ AVERAGE LENGHT } & 3.3 & 2.11 & & \\
\hline \multicolumn{2}{|c|}{ STANDARD DEVIATION } & 2.291 & 1.536 & & \\
\hline \multicolumn{2}{|c|}{ AVERAGE AMPLITUDE } & -0.0963 & 0.0661 & & \\
\hline \multicolumn{2}{|c|}{$\begin{array}{l}\text { AVERAGE CUMULATIVE } \\
\text { MOVEMENT }\end{array}$} & -0.2764 & 0.1129 & & \\
\hline
\end{tabular}

Notes: Turning points in the poverty cycles were calculated using SBBQ: Stata module to implement the Harding and Pagan (2002) business cycle dating algorithm, author Philippe Bracke and BBQ program, author Adrian Pagan. 


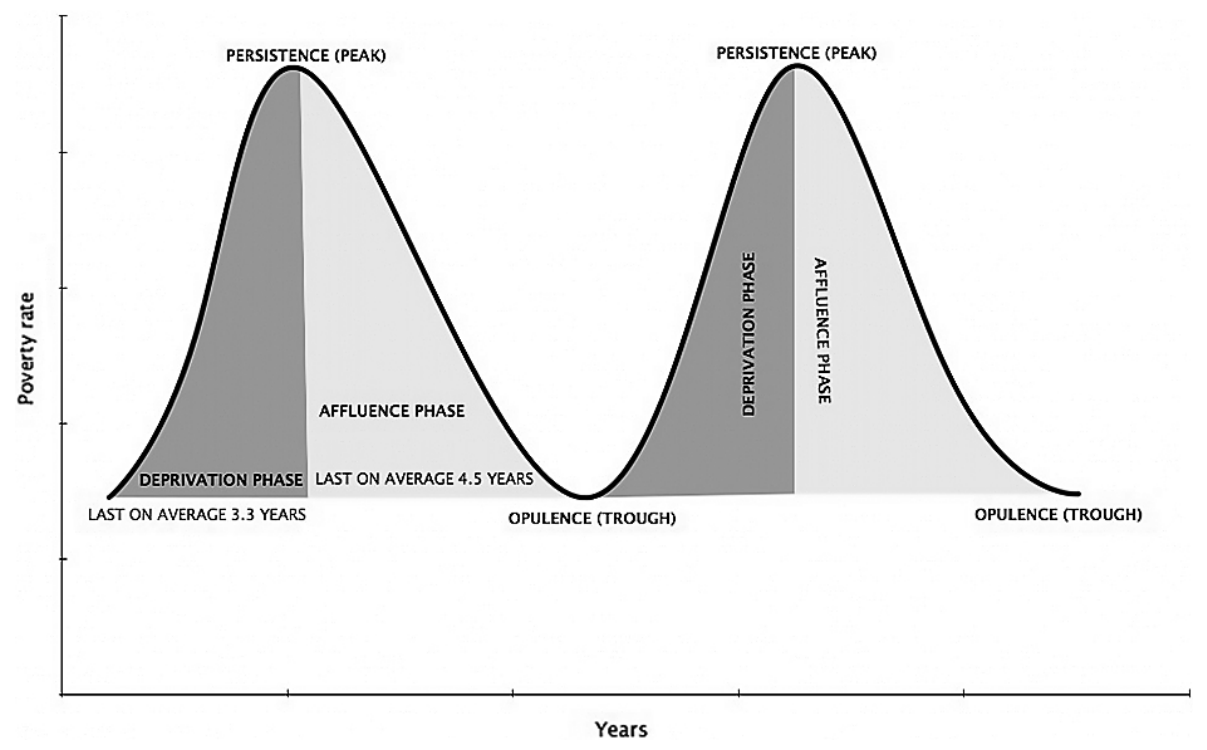

Figure 3. The poverty cycle (source: authors')

The deprivation phase is more pronounced, meaning that less time is needed for people to move from deprivation to poverty. On the other hand, the affluence phase is less pronounced (longer), and people need more time to escape from poverty (move from persistence to opulence). The average amplitudes for upswings and downswings are different in magnitude. The average amplitude for downswings (affluence) is -0.1884 and for upswings (deprivation) 0.153 . A fall in the poverty rate is almost evenly matched with rises in the poverty rate. Since falls in poverty rate are almost evenly followed with rises in poverty, Pareto efficiency holds. For downswings, the average cumulative movement is -0.6974 , and for upswings, the average cumulative movement equals 0.3846 . The average cumulative movement in downswings is twice the magnitude of the cumulative movements in upswings (longer average duration of downswings or affluence). Upswings (deprivation phase) in the poverty rate exhibit positive duration dependence (average duration is higher than the standard deviation). Positive duration dependence in poverty rates upswings shows the probability of exiting the deprivation phase about its duration. Since the average duration of the deprivation phase in the poverty rate is higher than its standard deviation, positive duration dependence in upswing exists. Positive duration dependence in the poverty rate suggests that the more prolonged deprivation phase lasts, people will face a higher probability of entering poverty. Individual probability of escaping poverty increases with the duration of the affluence phase. Results support the finding that both deprivation and affluence are strongly duration dependent. Results also stress the difference between the traditional business cycles findings with recessions being duration dependent and expansions mainly duration independent (Diebold \& Rudebusch, 1990); (Diebold, Rudebusch, \& Sichel, 1993); (Sichel, 1991); (Durland \& McCurdy, 1994); (Watson, 1994). 


\section{Poverty cycle shapes and duration analysis - (families)}

The shape of poverty cycles for families is quite similar to the one for individual poor. The cycles average phase is identical to the individual cycles with 4.57, years for downswings and 3.33 years for upswings. Some cycle periods are the same - six periods of downswings and six periods of upswings. Standard deviation is also unchanged with 3.386 years standard deviation for downswings and 1.505 years for upswings. The average amplitude of drop in the poverty rate (downswings) equals -0.2112 (not significantly different from the value calculated for poor individuals). Average amplitude for upswings is 0.1694 , very close to the 0.153 measured for individuals below the poverty threshold. Pareto efficiency principle thus holds for families as well. Average cumulative movement for downswings is -0.7828 and for upswings 0.4192 . Both values are once again very close to the calculated values for individuals identified as poor and presented above. That is consistent with the fact that affluence lasts longer about deprivation. In fact, this resembles business cycles and contraction having longer average duration compared to upswings. However, in poverty cycles, families fall into poverty quicker than exiting from them. Deprivation in hard times hits families harsh and quickly lead them to poverty. Affluence in good times coming from an increase in income takes longer to take effect on families. That shows that income growth is essential to fight poverty but growth distribution (trickle down) is even more critical for families to escape from the poverty trap. It also implies the lack of some poverty stabilizers to protect potentially poor families in time of crisis. When the crisis hits, potentially poor families are first to go (three years on average to fall into poverty). Protective buffers should be in place for them in time of crisis since driving them into poverty prolongs the crisis through a much stronger decline in aggregate demand. Poor families (the same as individuals) spend more time escaping from poverty than rushing into poverty. Thus, results point to the conclusion that variables causing poverty (running into poverty) have a stronger and faster impact about variables alleviating poverty (escaping from poverty). Remember that upswings and downswings are opposite regarding the poverty cycles about the same terms in business cycles. People and families quickly become poor but exit from poverty very slowly.

\section{Poverty cycle shapes and duration analysis - (unrelated individuals)}

Although not highly synchronized with business cycles, poverty cycles for unrelated individuals are more prominent about the poverty cycles for all people and families. The average length of the affluence phase is 4.38 and for the deprivation phase 2.42 . About other poverty measures, the deprivation phase for unrelated individuals is even less pronounced, so they rapidly fall into poverty (almost ten months faster). This fact is quite impressive since poverty cycles for unrelated individuals are not highly synchronized with business cycles. That means that unrelated individuals fall into poverty more often and rapidly about families and all people but the decrease in their median and mean income is not a direct cause. The affluence phase is shorter ( 3 months) about the observed affluence phase for all people and families in poverty. Unrelated individuals need 4.38 years to escape from poverty (move from the poverty persistence state to the opulence state and reach the poverty rate trough). The average amplitude for downswings (affluence phase) is -0.154 and for upswings (deprivation phase) 
0.075. In contrast to the in/out poverty phase synchronization observed for all people and families in poverty, a fall in the poverty rate for unrelated individuals is not evenly matched with the rise in poverty. Unrelated individuals once escaping from poverty manage to stay out of it. For every 2 persons escaping from the poverty trap, only 1 is likely to fall into the trap again. These results are entirely different from the results for all people and families in poverty. The average person or families escaping poverty have a high probability (80-90\%) of falling into the poverty trap again. That does not hold for the related individuals with the associated probability of falling into the poverty trap again after escaping the poverty of $50 \%$. Social relations (single or family member) and associated poverty thresholds depending upon the size of the family and related expenditure seem to have a direct consequence on the in/ out poverty dynamics. Single men or women are more successful in escaping and staying out of poverty; they have lower poverty persistence rate.

\section{Poverty cycle shapes and duration analysis - (families, female householder)}

Poverty cycles for families with female householders are the longest and most prominent. The average length of the affluence phase is 3.3 and for the deprivation phase 2.11. Compared to other poverty indicators (people and families), deprivation phase for families with female householder is the shortest and lasts 2.11 years (average phase to enter poverty). Poverty cycles for families with female householders are actively synchronized with business cycles in the U.S. In most cases their length coincides with business cycle length, but in some instance, they are more prominent and last longer (cycles of 2000-2005 and 2007-2009). Families with female householders enter poverty frequently and rapidly when compared to people (all persons, unrelated individuals) and families. Their poverty cycles are highly synchronized with changes in output and income. That is expected because of the gender wage gap present on the U.S. labor market. The affluence phase last 3.3 years so families with female householder need 3.3 years to escape from poverty (move from the deprivation to the affluence phase). The average amplitude for contraction (affluence phase) is -0.09 , and for upswings (deprivation phase) 0.07 . The phase synchronization for families with female householder (in/ out poverty dynamics) is high. Families with female householder are always under pressure of reentering poverty after escaping from the poverty threshold. For a single family with a female householder, escaping from poverty trap seems only to be temporary (they are likely to fall into poverty again). A family with a female householder escaping poverty has a high probability $(72 \%)$ to fall into the poverty trap again. Poverty dynamics for families with female householders are highly sensitive to business cycles and income fluctuations. That is because of the gender income gap but also the unemployment gender gap. In a time when average income shrinks, total household income for families with female householder automatically shrinks too. Whenever unemployment is rising in a time of crisis families with female householder are the one to enter the unemployment workforce. Because of the apparent income gender gap and unemployment gender gap, families with female householder have high poverty persistence rate (they have a hard time in escaping from poverty) and when succeeding it is only temporary. 


\section{Conclusions}

Poverty cycles are a fact and deserve to be studied with the same intensity as business cycles in the body of literature. Their effect on the economy is substantial when it comes to influencing future output, resulting in a balanced or unbalanced country's economic growth. Business cycles and poverty cycles are two sides of the same coin - economic development. The design of efficient economic policies to fight poverty demands empirical knowledge on poverty cycles (duration, phases, duration dependences, volatility). Concise and useful poverty policy guidelines from policymakers cannot be designed without such empirical knowledge on the dynamics of poverty cycles.

Poverty cycles differ among people and families depending on the age structure, education, type of household, gender. That, in turn, affect the volatility of poverty cycles, having a sizeable negative impact on people and families exposed to them. The higher the volatility of poverty cycles the severer the poverty persistence for individuals and families. People and families with higher poverty cycle volatility fall into deeper poverty traps which are difficult to escape. Once escaping from the poverty trap, they still retain a high level of probability to fall into the poverty trap again in the future. That is particularly true for families of unrelated individuals and families with female householders (income deficit and wage gender gap). Average poverty cycles for families and all persons last 4.57 years for the affluence phase (peak to trough when poverty rate falls) and 3.33 years for the deprivation phase (previous trough to peak when poverty rate rises). Average amplitude in poverty cycles for both categories is similar signaling that Pareto principle holds - the fall in poverty rate is equaled by the rise in the poverty rate. People and families fall into the poverty quickly while escaping from poverty demands more time. The same conclusion holds for families (unrelated individuals) with female householders. On average the 'fall into poverty' phase lasts 2 years and the 'escape from poverty' phase 3.3-4.3 years. For both categories, the probability of falling back into poverty is greater about all persons and families' group.

There is a clear link between poverty and business cycles but the effects of business cycles (change in income) varies according to the family structure (gender, education, age). High income level is essential but not sufficient to pool out people living in poverty out. When U.S. economy is doing well fewer people live in poverty but families and specially families with female householder are more affected by sudden change in income. Our results also support the thesis that poverty persistence lead families with/without female householder into poverty traps that often extend over few generations. Fight over poverty must not rest only on achieving higher income levels but also on specially designed social and poverty alleviation policies to fight poverty persistence.

This study is limited by the date used in the analysis. To derive poverty cycles, we need a sufficiently long time series data on poverty. Such a database is unfortunately only available for a limited number of countries. To carry out pioneering research on the poverty cycles presented here we choose the U.S. poverty database as a source of data, being more statistically robust about other countries. For the goal of isolating poverty cycles, we have selected a BBQ algorithm for isolating turning points in the cycles. Other, more advanced techniques can be used to isolate turning points in poverty cycles, offering more robust empirical data on 
the matter. Poverty cycles should also be explored for a more extensive sample of countries because of the differences in poverty nature which unambiguously affects poverty cycles.

Our is the first research, to our knowledge at least, to address the issue of poverty cycles and their dynamics. We consider exploring poverty cycles imperative to gaining empirical knowledge on the dynamics of poverty for policymakers to design effective economic policies to fight poverty. Without such empirical knowledge, resources devoted to fighting poverty will be wastefully used, having a minor impact on the poverty rate. Having empirical knowledge on the nature of poverty cycle dynamics will help policymakers in designing policies to fight but also prevent (or at least alleviate) poverty which is one of the most important macroeconomic goals for any economy. Future research on the poverty cycles should rely on more advanced econometric and spectral techniques. Using state of the art techniques to isolate turning points in poverty cycles could strengthen the confidence of the results. It would then be possible to analyze poverty cycles over a larger sample of countries and preferably for different groups (children, unemployed, disabled persons, ethnic, gender groups) as in Mood (2015).

\section{Acknowledgements}

This work has been fully supported by Croatian science foundation under the project number 9481 Modelling Economic Growth - Advanced Sequencing and Forecasting Algorithm.

\section{References}

Adato, M., Carter, R. M., \& May, J. (2006). Exploring poverty traps and social exclusion in South Africa using qualitative and quantitative data. Journal of Development Studies, 42(2), 225-247. https://doi.org/10.1080/00220380500405345

Addison, T., Hulme, D., \& Kanbur, R. (2009). Poverty dynamics: measurement and understanding from an interdisciplinary perspective. In T. Addison, D. Hulme \& R. Kanbur (Eds.), Poverty dynamics: Interdisciplinary perspectives (pp. 3-26). Oxford, UK: Oxford University Press. https://doi.org/10.1093/acprof:oso/9780199557547.003.0001

Alem, Y. (2015). Poverty persistence and intra-household heterogeneity in occupations: Evidence from Urban Ethiopia. Oxford Development Studies, 43(1), 20-43. https://doi.org/10.1080/13600818.2014.944123

Azam, M., Haseeb, M., \& Samsudin, S. (2016). The impact of foreign remittances on poverty alleviation. Global Evidence, Economics and Sociology, 9(1), 264-281. https://doi.org/10.14254/2071-789X.2016/9-1/18

Bane, M. J., \& Ellwood, D. T. (1986). Slipping into and out of poverty: The dynamics of spells. Journal of Human Resources, 21(1), 1-23. https://doi.org/10.2307/145955

Biewen, M. (2006). Who are the chronic poor? An econometric analysis of chronic poverty in Germany. In J. Creedy \& G. Kalb (Eds.) Research on Economic Inequality (Vol. 13), Dynamics of inequality and Poverty. UK, Netherlands, USA: Elsevier. https://doi.org/10.1016/S1049-2585(06)13002-1

Bradbury, B., Jenkins, S. P., \& Micklewright, J. (2001). The dynamics of child poverty in industrialised countries. Cambridge: Cambridge University Press. https://doi.org/10.1017/CBO9780511522147 
Cardinale, J., \& Taylor, L. W. (2009). Economic cycles: Asymmetries, persistence, and synchronization. In T. Mills, \& K. Patterson (Eds), Palgrave handbook of econometrics 2 (Chapter 7). Palgrave MacMillan. https://doi.org/10.1057/9780230244405_7

Carter, M., \& Barrett, C. (2006). The economics of poverty traps and persistent poverty: An asset-based approach. The Journal of Development Studies, 42(2), 178-199.

https://doi.org/10.1080/00220380500405261

Diebold, F. X., \& Rudebusch, G. D. (1990). A nonparametric investigation of duration dependence in the American business cycle. The Journal of Political Economy, 98(3), 596-616. https://doi.org/10.1086/261696

Diebold, F. X., Rudebusch, G. D., \& Sichel, D. (1993). Further evidence on business-cycle duration dependence. In J. H. Stock, M. W. Watson (Eds.), Business cycles, indicators and forecasting. University of Chicago Press.

Durland, J. M., \& McCurdy, T. M. (1994). Duration-dependent transitions in a Markov model of US GNP growth. Journal of Business \& Economic Statistics, 12(3), 279-288.

Harding, D., \& Pagan, A. (2002). Dissecting the cycle: A methodological investigation. Journal of Monetary Economics, 49(2), 365-381. https://doi.org/10.1016/S0304-3932(01)00108-8

Hulme, D., \& Sheperd, A. (2003). Conceptualizing chronic poverty. World Development, 31(3), 403-423. https://doi.org/10.1016/S0305-750X(02)00222-X

Kakwani, N., Neri, M. C., \& Son, H. H. (2010). Linkages between pro-poor growth, social programs and labor market: the recent Brazilian experience. World Development, 38(6), 881-894. https://doi.org/10.1016/j.worlddev.2010.02.015

Khan, W., Shaorong, S., \& Ullah, I. (2017). Doing business with the poor: the rules and impact of the microfinance institutions. Economic Research - Ekonomska Istraživanja, 30(1), 951-963. https://doi.org/10.1080/1331677X.2017.1314790

Krishna, A. (2006). Pathways out of and into poverty in 36 villages of Andhra Pradesh, India. World Development, 34(2), 271-288. https://doi.org/10.1016/j.worlddev.2005.08.003

Mangum, G. L., Mangum, S. L., \& Sum, A. M. (2003). The persistence of poverty in the United States. Baltimore and London: The Johns Hopkins University Press.

Mood, C. (2015). The not-very-rich and the very poor: Poverty persistence and poverty concentration in Sweden. Journal of European Social Policy, 25(3), 316-330. https://doi.org/10.1177/0958928715588707

Mosse, D. (2010). A relational approach to durable poverty, inequality and power. The Journal of Development Studies, 46(7), 1156-1178. https://doi.org/10.1080/00220388.2010.487095

Mudambi, R., \& Taylor, L.W. (1995). Some non-parametric tests for duration dependence: An application to UK business cycle data. Journal of Applied Statistics, 22(1), 163-177. https://doi.org/10.1080/757584405

Muyanga, M., Jayne, T. S., \& Burke, W. J. (2013). Pathways into and out of Poverty: A study of rural household wealth dynamics in Kenya. The Journal of Development Studies, 49(10), 1358-1374. https://doi.org/10.1080/00220388.2013.812197

Ohn, J., Taylor, L. W., \& Pagan, A. (2004). Testing for duration dependence in economic cycles. The Econometrics Journal, 7(2), 528-549. https://doi.org/10.1111/j.1368-423X.2004.00142.X

Oxley, H., Dang, T. T., \& Antolín, P. (2000). Poverty dynamics in six OECD countries. OECD Economic Studies, 30(1), 7-52.

Perry, G. E., Arias, O. S., López, J. H., Maloney, W. F., \& Servén, L. (2006). Poverty reduction and growth: virtuous and vicious circles. The World Bank, Washington.

https://doi.org/10.1596/978-0-8213-6511-3 
Ruggles, P., \& Williams, R. (1986). Transitions in and out of poverty: New data from the survey of income and program participation. Publication No. 8716. Washington, DC: Bureau of the Census.

Sichel, D. E. (1991). Business cycle duration dependence: A parametric approach. Review of Economics and Statistics, 73(2), 254-260. https://doi.org/10.2307/2109515

Simionescu, M. (2016). Competitiveness and economic growth in Romanian regions. Journal of Competitiveness, 8(4), 46-60. https://doi.org/10.7441/joc.2016.04.03

Sodeyfi, S., \& Katircioglu, S. (2016). Interactions between business conditions, economic growth and crude oil prices. Economic Research - Ekonomska Istraživanja, 29(1), 980-990. https://doi.org/10.1080/1331677X.2016.1235504

Stevens, A. H. (2012). Poverty transition. In P. N. Jefferson (Ed.), The Economics of poverty (Chapter 15). USA: Oxford University Press. https://doi.org/10.1093/oxfordhb/9780195393781.013.0016

Watson, M. W. (1994). Business-cycle durations and post-war stabilization of the US Economy. American Economic Review, 84(1), 24-46.

Yelognisse, A. D. (2016). On poverty and the persistence of poverty in Benin. Journal of Economic Studies, 43(4), 661-676. https://doi.org/10.1108/JES-12-2014-0205 